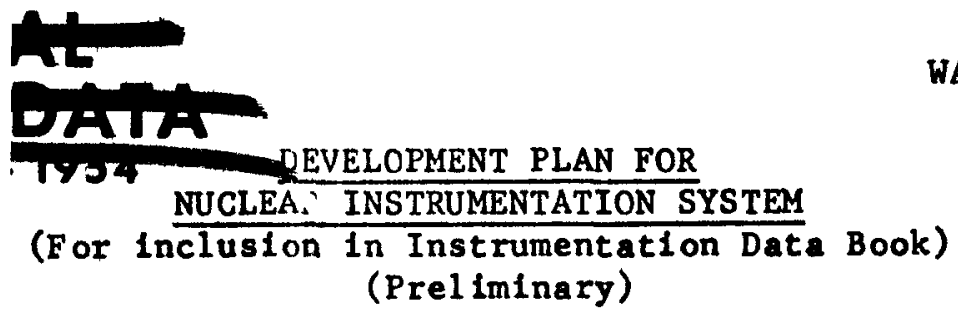

WANL - TME - 258

\author{
TYS4 DEVELOPMENT PLAN FOR \\ NUCLEA: INSTRUMENTATION SYSTEM \\ (Prel iminary)
}

APPLICATION

Reactor neutron flux must be measured and calibrated as reactor power for control purposes. Reactor power must be so measured over ten decades of power level. Nuclear instrumentation must convert low level neutron detector signals to a logarithmic analog signal of reactor power. This analog power signal must be of a sufficient impedance level to be used by control system amplifiers.

Neutron detector and instrumentation calibration requires three ranges of measurement to cover the ten decades of power required. Fission counter neutron detectors w11 be used in source and intermediate range land an lonization chamber detectar wII be used for the power range neutron filux measurements. Five decades of power covertng $10^{-5}$ to full power wiI be measured by the power range instrumentation channels. Intermediate range instrumentation channels will measure four decades of power from $10^{-8}$ to $10^{-4}$ of full power. Source range instrumentation channels w111 measure 3 decades of power from $10-10$ to $10^{-6}$ of full power. Overlapping decades w1ll be used for switching and calibration purposes in the control system.

\title{
OBJECTIVE
}

Nuclear instrumentation must be designed to satisfy the following requirements:

1. Preamplifiers and coaxial cables must be sultable for transmitting neutron detector signals to the payload area instrumentation when subject to a fast neutron flux of $1.2 \times 10^{12} \mathrm{n} / \mathrm{cm}^{2} \mathrm{sec} . E>2.9 \mathrm{Mev}$, a thermal neutron flux of $1010 \mathrm{n} / \mathrm{cm}^{2} \mathrm{sec}$, and gamma dose rate of $5 \times 10^{7} \mathrm{R} / \mathrm{hour}$. Thfs equipment must survive intermittent exposures to this flux for up to pne hour total integrated exposure.

2. Three ranges of instrumentation covering 4 or 5 decades each with qverlap w11l be used to span the 10 decade measurement requirement. Independent redundant circuits will be used to satisfy control system reliablifty requirements.

3. The complete system must perform satisfactorily in a vibration environment of $10 \mathrm{~g}^{\prime} \mathrm{s}$ from 20 to 2000 cycles per second.

4. The system must be capable of operation from one atmosphere to $1 \times 10^{-6} \mathrm{~mm} \mathrm{Hg}$ pressure. Payload equipment must operate over an ambient temperature range of $-40^{\circ} \mathrm{C}$ to $+80^{\circ} \mathrm{C}$. Preamplifiers, wiring and coaxial cables must operate from cryogenic temperatures to $200^{\circ} \mathrm{C}$.

5. A worst case response time of one second must be satisfled.

\section{PROBLEM AREAS}

Several Important design problems are 11sted here for emphasis. Development and testing in these areas are imperative: 


\section{DISCLAIMER}

This report was prepared as an account of work sponsored by an agency of the United States Government. Neither the United States Government nor any agency Thereof, nor any of their employees, makes any warranty, express or implied, or assumes any legal liability or responsibility for the accuracy, completeness, or usefulness of any information, apparatus, product, or process disclosed, or represents that its use would not infringe privately owned rights. Reference herein to any specific commercial product, process, or service by trade name, trademark, manufacturer, or otherwise does not necessarily constitute or imply its endorsement, recommendation, or favoring by the United States Government or any agency thereof. The views and opinions of authors expressed herein do not necessarily state or reflect those of the United States Government or any agency thereof. 


\section{DISCLAIMER}

Portions of this document may be illegible in electronic image products. Images are produced from the best available original document. 
1. Coaxial cables and wiring must withstand severe temperatures and nuclear radiation environments while maintaining mechanical and electrical pro-

perties.

2. Electronic packaging techniques capable of surviving the nuclear environment while providing component cooling under zero gravity and vacuum conditions must be developed.

3. Reliability of circultry capable of surviving the nuclear environment must be established.

4. Circuits and packaging techniques for the payload instrument circuitry must be developed satisfying space environment and system reliability requirements.

5. Methods of installation of cables and instrumentation must be established to minimize the detrimentel effects of the NERVA environment in order to Improve rellability.

RESEARCH AND ANALYSIS

A continuing research program in simulated NERVA environments is required to secure reliable circults and components.

Recently completed experiments at Western New York Research Center's test reactor have estabilshed possible solutions to the nuclear environment problems. Th1s basic research must now be proven by test of systems incorporating determined techniques.

\section{DEVELOPMENT APPROACH}

The development of the nuclear instrumentation 1 s being conducted as follows:

Three ranges of instrumentation power, intermediate and source ranges are being developed for respective neutron detectors.

1. The power range nuclear Instrumentation consists of a $10 \mathrm{~g}$ microammeter to be located In the payload area and utilizing coaxial cables to the lon chamber (neutron detector) located on top of the reactor shield.

Tests have indicated this approach to be sultable for detector signals over the range of $10^{-8}$ to $10^{-3}$ amperes.

2. Intermediate range and source range instrumentation is being developed utflizing radiation hardened pulse preamplifiers located at the neutron detector (fission counter) on top of the reactor shield. Preamplifier output is coupled via coaxial cable to payload pulse integrating c1rcultry. Operating range w111 be 50 to 500,000 counts per second including overlap. 
3. Each range of instrumentation 1 being designed to deliver $0-5$ volt output

.. signal (1 volt per decade of neutron power) to a $2,500 \mathrm{ohm}$ control syatem load. An accuracy of $\pm 10 \%$ of indicated power is the present design objective.

PROPOSED TESTS

The following items will be tested under separate and/or combined NERVA environmental conditions as required to establish reliable performance:

1. Electronic components and pulse preamplifiers.

2. Coaxial cables (algnal and high voltage).

3. Insulating materials and circuit boards.

4. Neutron detectors and assoclated clrcultry (Including NRX tests).

Approved:

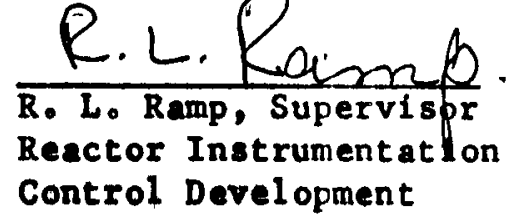

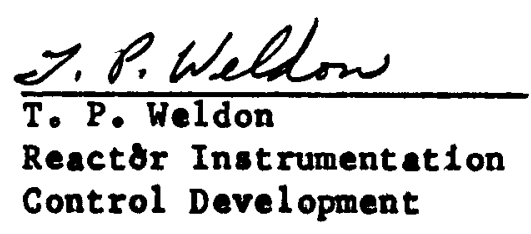

IJIx

This report was preparice

sponsored by was prepared as an account of work the United States nited States Government Neither Research and Developor the United States Energy their employees, nor administration, nor any of subcontractors, or their of their contractors, warranty, express or their employees, makes any liablity or responsibulity for the or assumes any legal or usefulness of any informathe accuracy, completeness process disclosed, or represents, apparatus, product or infringe privately owned resents that its use would not 